\title{
EDITORS’ REMARKS
}

What role did rural villagers play in the formation of industrial capitalism? The question arises not only in connection with the industrialization of Europe and North America, but also in our analysis of Asian, African, and Latin American economies, both historically and in the present day. Historians of early modern Europe, impressed by the integration of cottage manufacturing with agricultural life in many regions, have often resorted to the concept of "protoindustrialization" in order to identify a phase of economic development prior to the advent of factory production in urban areas.

Jean Quataert has devoted the Scholarly Controversy of this issue to an assessment of that concept, which, she argues, has undergone considerable modification since it was first introduced into historical discourse. The relationship of merchant capital to peasant households, some or all members of which engaged in manufacturing, assumed a wide variety of configurations and was by no means confined to pastoral villages. Villagers themselves, and especially the women, were active agents in creating the various productive, familial, and cultural patterns that linked their places of residence to the domain of merchant capital. Although in Quataert's view the best analyses of this relationship emphasize the role of land-poor peasants, they dispute earlier linear conceptions of proletarianization, and especially the demographic predictions associated with those interpretations. They also challenge the explanation of the development of world capitalism in terms of transformations forced upon a passive periphery by the actions of a dynamic North Atlantic core. There have been more paths to economic development, Quataert concludes, than the roads that passed through Manchester and Pittsburgh.

Quataert's critics respond to her arguments in quite different ways. Jonathan Prude summons historians of the United States to pay close attention to her analysis of other parts of the world, and especially to her discussion of continuity and change in the countryside. Americanists, with their eyes fixed on the rise of the factory, have conducted quite a muddled debate over the capitalist transformation of rural life, especially in the northern states. He also expresses the fear, however, that too great an emphasis on continuities might distract attention from the extent of social change that did take place in American farming communities. Charles Sabel, on the other hand, argues that the time has arrived to discard the concept of capitalism itself. Identifying protoindustry with the organization of manufacture before the conspicuous application of machinery, Sabel contends that the varieties of economic development do not permit us to speak of any laws of social evolution. From his point of view, 
concern with the transition from one social system to another only inhibits creative thought.

Industrialization on a massive scale and at breakneck speed was experienced by the tens of thousands of foreign workers who contributed their skills to the planned creation of a factory system of massive proportions in the Soviet Union between the two world wars. The testimony of those workers has been examined by Andrea Graziosi in order to learn both what they revealed about the lives of workers in the USSR and what impact their revelations had on workers' movements in the countries from which they had come. The experience of these workers provides a remarkable source for the study of Soviet social history. The abundance of their accounts suggests that firsthand information about the actualities of life under the Five-Year Plans was widely accessible to workers in the industrialized countries.

Ronald Suny's review essay connects the historiography of Soviet and Western workers by a different route. He shows that the innovations in Marxism that have had such an impact on the study of west European and North American workers during the last generation are now being applied tentatively to the experiences and actions of industrial workers in the USSR, especially during the twenties and thirties. Mary Nolan's review essay deals with the social history of communist movements on the more familiar terrain of the Weimar Republic. She reflects on the political violence in working-class neighborhoods during that period and asks what it reveals about the meaning of communism to young German workers.

As we enjoy these insights from the social history of the working class, we must also pause sadly to mark our collective loss through the recent death of Harvey Goldberg. He was, above all, a brilliant teacher in the full sense of the term: passionate, engaged, learned, and able to inspire in his students the desire to know more and to study further the history of working-class movements. In his legendary course in European Social History at Wisconsin, to which as many as eight hundred people flocked at a time, he evoked the life and blood of labor struggles. Many of his auditors were inspired to follow Goldberg's footsteps into the world of scholarship. Anyone entering a French archive in the past two decades has been certain to find at least one of his students there. His untimely death has shocked us all; his example and influence remain a living force.

D. M. and H. G. 